\title{
Penambahan Gula untuk Meningkatkan Pertumbuhan dan Antagonisme Khamir Rhodotorula minuta terhadap Colletotrichum acutatum Penyebab Antraknosa Cabai secara In-vitro
}

\author{
Sri Hartati ${ }^{1}$, Wahyu Daradjat Natawigena ${ }^{1}$, Noor Istifadah ${ }^{1}$ dan Sri Rosmala Dewi ${ }^{2}$ \\ ${ }^{1}$ Departemen Hama dan Penyakit Tumbuhan, Fakultas Pertanian, Universitas Padjadjaran \\ ${ }^{2}$ Alumnus DHPT, Fakultas Pertanian, Universitas Padjadjaran \\ Jl. Raya Bandung-Sumedang KM 21 Jatinangor 40600 \\ AAlamat korespondensi: s.hartati@unpad ac.id
}

\begin{abstract}
The addition of sugar to increase the growth and antagonism of Rhodotorula minuta against Colletotrichum acutatum, the causal agent of anthracnose on chilli in-vitro
\end{abstract}

Biocontrol can be used as an alternative in controlling anthracnose disease on chilli caused by Colletotrichum acutatum. One of the antagonistic agents that reported to be able to control anthracnose on chilli is Rhodotorula minuta. Some sugars can be utilized by $R$. minuta for its growth and antagonism. This research was objected to study the effect of addition of some sugars to increase the growth and antagonism of $R$. minuta. The experiment was arranged in the completely randomized design with 16 treatments and 3 replications. The treatments were addition of glucose, sucrose, trehalose, D-mannitol, and D-xylose at $1 \%, 2.5 \%$ and $5 \%$ each. The results showed that the addition of glucose, sucrose, trehalose, D-mannitol, and D-xylose were able to increase the growth of $R$. minuta. The addition of glucose, sucrose, trehalose, and D-mannitol increased antagonism of $R$. minuta. The addition of $1 \%$ sucrose was able to stimulate the highest growth rate of $R$. minuta at the cell density of $3.87 \times 10^{7}$ cells $/ \mathrm{ml}$. The addition of trehalosa $2.5 \%$ increased the colony growth at 3 and 6 days after treatment. Sucrose 2.5\%, D-manitol 5\%, and glukosa 2,5\% caused the highest relative inhibition of $R$. minuta against $C$. acutatum.

Key words: antagonistic yeast, glucose, sucrose, trehalose, D-mannitol, D-xylose

\begin{abstract}
ABSTRAK
Pengendalian hayati dapat digunakan sebagai alternatif dalam mengendalikan penyakit antraknosa pada cabai. Salah satu agens antagonis yang telah dilaporkan mampu mengendalikan penyakit antraknosa pada cabai yang disebabkan oleh Colletotrichum acutatum adalah khamir Rhodotorula minuta. Beberapa gula dapat dimanfaatkan oleh $R$. minuta untuk pertumbuhan dan antagonismenya. Penelitian ini bertujuan untuk mengetahui pengaruh penambahan beberapa gula untuk meningkatkan pertumbuhan dan antagonisme $R$. minuta. Percobaan dilakukan dengan menggunakan rancangan acak lengkap yang terdiri dari 16 perlakuan dan tiga ulangan. Perlakuan terdiri dari penambahan gula glukosa, sukroa, trehalosa, D-mannitol dan D-xylose dengan konsentrasi masing-masing gula $1 \%, 2,5 \%$ dan $5 \%$. Hasil percobaan menunjukkan bahwa penambahan gula glukosa, sukrosa, trehalosa, D-mannitol, dan D-xylose dapat meningkatkan pertumbuhan $R$. minuta. Penambahan gula glukosa, sukrosa, trehalosa, dan D-mannitol dapat meningkatkan antagonisme $R$. minuta. Perlakuan penambahan gula sukrosa $1 \%$ merupakan perlakuan yang dapat meningkatkan pertumbuhan $R$. minuta dengan kerapatan sel tertinggi yaitu sebesar $3,87 \times 10^{7} \mathrm{sel} / \mathrm{ml}$. Penambahan trehalosa 2,5\% dapat meningkatkan pertumbuhan koloni pada 3 HSP dan 6 HSP. Sukrosa 2,5\%, D-manitol 5\% dan glukosa 2,5\% menyebabkan tingkat hambatan relatif $R$. minuta tertinggi terhadap $C$. acutatum.
\end{abstract}

Kata kunci : Khamir antagonis, glukosa, sukrosa, trehalosa, D-mannitol, D-xylosa 


\section{PENDAHULUAN}

Penyakit antraknosa merupakan salah satu penyakit penting pada tanaman cabai. Kerugian petani cabai akibat penyakit antraknosa dapat mencapai $20-90 \%$ (Badan Litbang Pertanian, 2016). Salah satu penyebab penyakit antraknosa adalah jamur Colletotrichum acutatum. Jamur C. acutatum dapat menyebabkan kehilangan hasil yang signifikan pada tanaman penghasil buah dan sayuran (Stankova et al., 2011). Jamur ini dapat menyerang lahan cabai di Indonesia seluas 5.541 ha (Susetyo, 2017).

Pengendalian hayati merupakan salah satu alternatif pengendalian yang ramah lingkungan. Saat ini, telah banyak jamur yang dilaporkan dapat dimanfaatkan dalam pengendalian hayati. Pemanfaatan jamur sebagai agens pengendali hayati yang telah dilaporkan diantaranya dari golongan khamir (Ahmad, 2008). Rhodotorula minuta merupakan salah satu khamir yang memiliki kemampuan sebagai agens antagonis terhadap $C$. acutatum penyebab antraknosa pada cabai (Hartati dkk., 2014).

Pertumbuhan mikroorganisme dipengaruhi oleh jenis gula, temperatur, $\mathrm{pH}$ dan aerasi. Beberapa gula dilaporkan dapat dimanfaatkan oleh mikroba diantaranya glukosa, sukrosa, molase dan tepung tapioka (Subagyo dkk., 2015). Khamir $R$. minuta mampu memanfaatkan beberapa gula untuk pertumbuhannya (Hartati dkk., 2017). Beberapa gula yang dapat dimanfaatkan oleh khamir tersebut diantaramya adalah D-Cellobiosa, D-Xylosa, NAcetyl-L-Glutamic Acid plus D-Xylosa, Quinic Acid plus D-Xylosa, D-Glucuronic Acid plus D-Xylosa, Dextrin plus D-Xylosa, $\alpha$-D-Lactosa plus D-Xylosa, D-Melibiosa plus D-Xylosa, D-Galactosa plus DXylosa, m-Inositol plus D-Xylosa, 1,2-Propaneditol plus D-Xylosa, Acetoin plus D-Xylosa, glukosa, galaktosa, sukrosa dan trehalosa (Hartati dkk., 2017).

Penambahan gula diketahui dapat meningkatkan pertumbuhan dan kemampuan antagonisme khamir terhadap patogen penyebab penyakit. Druvefors (2004) melaporkan bahwa penambahan gula glukosa dan maltosa dapat meningkatkan pertumbuhan dan antagonisme khamir Pichia anomala terhadap Penicillium roquefortii pada biji gandum. Penambahan gula glukosa dapat meningkatkan pertumbuhan khamir patogenik Candida albicans (Leepel dkk., 2009).

Konsentrasi gula yang digunakan dalam meningkatkan pertumbuhan dan antagonisme mikroba akan menghasilkan tingkat pertumbuhan dan antagonisme yang berbeda. Menurut Leepel dkk. (2009) semakin tinggi konsentrasi glukosa yang ditambahkan, semakin bertambah pertumbuhan $C$. albicans. Addy (2008) melaporkan bahwa penambahan glukosa $2 \%$ dapat meningkatkan kemampuan penghambatan Pseudomonas fluorescent terhadap Erwinia caratovora, sedangkan penambahan glukosa $5 \%$ menyebabkan penurunan daya hambat $P$. fluorescent. Akan tetapi, penambahan gula manitol 5\% menyebabkan daya hambat $P$. fluorescent meningkat dibandingkan penambahan gula manitol 2\%. Penelitian ini bertujuan untuk mengetahui pengaruh penambahan gula glukosa, sukrosa, trehalosa, D-xylosa dan Dmannitol untuk meningkatkan pertumbuhan dan antagonisme $R$. minuta.

\section{BAHAN DAN METODE}

Penelitian dilaksanakan di Laboratorium Bioteknologi Proteksi Tanaman, Fakultas Pertanian, Universitas Padjadjaran dari Februari sampai Juni 2018. Penelitian dilaksanakan dengan menggunakan metode eksperimen menggunakan Rancangan Acak Lengkap (RAL) dengan 16 perlakuan dan 3 ulangan. Media yang digunakan untuk pengujian pengaruh penambahan gula terhadap pertumbuhan dan antagonisme $R$. minuta terhadap $C$. acutatum adalah PDA dengan $10 \mathrm{~g}$ dextrose. Perlakuan pada penelitian ini adalah:

A. Penambahan gula glukosa $1 \%$

B. Penambahan gula glukosa $2,5 \%$

C. Penambahan gula glukosa $5 \%$

D. Penambahan gula sukrosa $1 \%$

E. Penambahan gula sukrosa $2,5 \%$

F. Penambahan gula sukrosa $5 \%$

G. Penambahan gula trehalosa $1 \%$

H. Penambahan gula trehalosa $2,5 \%$

I. Penambahan gula trehalosa 5\%

J. Penambahan gula D-mannitol 1\%

K. Penambahan gula D-mannitol 2,5\%

L. Penambahan gula D-mannitol 5\%

M. Penambahan gula D-xylosa $1 \%$

N. Penambahan gula D-xylosa $2,5 \%$

O. Penambahan gula D-xylosa $5 \%$

P. Kontrol tanpa penambahan gula

Penyiapan Biakan Murni $R$. minuta dan C. acutatum Khamir $R$. minuta merupakan koleksi Laboratorium Bioteknologi Proteksi Tanaman, 
Fakultas Pertanian, Universitas Padjadjaran, yang selanjutnya diremajakan dan diperbanyak. Biakan murni $R$. minuta ditumbuhkan pada media PDA dengan cara digores. Biakan diinkubasi selama 5-7 hari sebelum digunakan untuk perlakuan.

Jamur C. acutatum didapatkan dari hasil isolasi buah cabai yang menunjukkan gejala antraknosa. Buah cabai yang menunjukkan gejala antraknosa tersebut berasal dari Desa Ciptagumati, Kecamatan Cikalong Wetan, Padalarang, Bandung. Isolasi jamur $C$. acutatum menggunakan media PDA dan diinkubasi pada suhu ruang selama 7-10 hari. Jamur yang tumbuh kemudian dimurnikan serta diidentifikasi secara morfologi dengan mengamati bentuk konidianya.

\section{Pengujian Pengaruh Penambahan Gula terhadap Kerapatan sel $R$. minuta}

Pengujian pengaruh penambahan gula yaitu glukosa, sukrosa, trehalosa, D-xylosa dan Dmannitol menggunakan akuades sebagai pelarutnya. Konsentrasi glukosa, sukrosa, trehalosa, D-xylosa dan D-mannitol yang diuji $1 \%, 2,5 \%$ dan $5 \%$ didapatkan dengan menambahkan gula tersebut dalam akuades pada Erlenmeyer sehingga didapatkan larutan dengan volume $100 \mathrm{ml}$. Erlenmeyer yang berisi akuades disterilkan dengan autoclave pada suhu $121^{\circ} \mathrm{C}$ dengan tekanan 1 atm selama 15 menit. Khamir $R$. minuta sebanyak 1 lup ose ditumbuhkan pada $100 \mathrm{ml}$ larutan gula dan dishaker selama 24, 48 dan 72 jam dengan kecepatan $100 \mathrm{rpm}$. Kontrol dibuat dengan cara yang sama tanpa penambahan gula. $\mathrm{pH}$ larutan gula diukur setiap hari menggunakan $\mathrm{pH}$ meter.

Pengamatan kerapatan sel $R$. minuta dilakukan pada 24, 48 dan 72 jam setelah inkubasi dalam shaker. Kerapatan sel $R$. minuta dihitung pada pengenceran $10^{-1}$ dengan metode hitung langsung menggunakan hemasitometer. Kerapatan sel dinyatakan dalam satuan sel/ml. Pengukuran $\mathrm{pH}$ dilakukan dengan menggunakan alat $\mathrm{pH}$ meter dengan cara memasukan elektroda dan stik pengukur ke dalam larutan yang dilakukan setiap 24 jam.

\section{Pengaruh Penambahan Gula terhadap Pertumbuhan Koloni $R$. minuta}

Pengujian pengaruh penambahan gula glukosa, sukrosa, trehalosa, D-xylosa dan Dmannitol terhadap pertumbuhan koloni $R$. minuta dilakukan dengan menggunakan media PDA $1 / 2$ dextrose. Gula tersebut ditambahkan pada saat membuat media PDA. Khamir $R$. minuta ditumbuhkan dengan cara menggores secara vertikal dengan panjang goresan $3 \mathrm{~cm}$ pada media PDA $1 / 2$ dextrose yang telah ditambahkan gula sesuai dengan perlakuan. Pengamatan pertumbuhan khamir dilakukan setiap hari sampai hari ke-14. Sebagai kontrol, $R$. minuta ditumbuhkan pada media PDA $1 / 2$ dextrose tanpa gula.

Pengamatan pengaruh penambahan gula terhadap pertumbuhan koloni $R$. minuta dilakukan dengan cara mengukur panjang dan lebar koloni khamir.

\section{Pengaruh Penambahan Gula terhadap Kemampuan Antagonisme $R$. minuta}

Pengaruh penambahan gula glukosa, sukrosa, trehalosa, D-xylosa dan D-mannitol terhadap kemampuan antagonisme $R$. minuta dilakukan secara in-vitro dengan metode triple culture. Khamir digoreskan pada media PDA $1 / 2$ dexktose tepat ditengah cawan petri secara tegak lurus. Jamur $C$. acutatum diambil dengan bor gabus ukuran $1,5 \mathrm{~cm}$ dan diletakkan pada sisi kanan dan kiri goresan khamir dengan jarak $3 \mathrm{~cm}$ kemudian diinkubasi pada suhu ruang. Kontrol dibuat dengan cara yang sama tanpa penambahan gula. Selain itu, dibuat perlakuan gula pada media PDA untuk melihat pengaruhnya terhadap pertumbuhan $C$. acutatum tanpa pemberian khamir $R$. minuta. Pengamatan terhadap zona hambat dan presentase tingkat penghambatan R. minuta dilakukan setiap hari.

Pengamatan pengaruh penambahan gula terhadap kemampuan antagonisme $R$. minuta dilakukan dengan cara mengukur jari-jari koloni $C$. acutatum yang tumbuh mendekati $R$. minuta. Tingkat hambatan relatif dihitung berdasarkan rumus sebagai berikut:

$$
T H R=\frac{j k-j p}{j k} \times 100 \%
$$

THR = tingkat hambatan relatif

$\mathrm{jk} \quad=$ jari-jari koloni patogen yang mengarah ke antagonis pada kontrol

jp = jari-jari koloni patogen yang mengarah ke antagonis pada perlakuan

Pengaruh Penambahan Gula terhadap Peningkatan Antagonisme $R$. minuta melalui Pembentukan Senyawa Volatil

Pengujian kemampuam amtagonisme melalui pembentukan senyawa volatil dilakukan dengan mengikuti metode Huang et al. (2014). Pengujian tersebut dilakukan dengan cara menggores $R$. minuta sebanyak 1 lup ose pada media PDA yang telah ditambah gula glukosa, sukrosa, trehalosa, D- 
xylosa dan D-mannitol dengan konsentrasi 1\%, 2,5\% dan $5 \%$ pada cawan petri dan menumbuhkan $C$. acutatum berdiameter $1,5 \mathrm{~cm}$ pada media PDA yang telah diberi perlakuan secara terpisah. Selanjutnya, kedua cawan petri tersebut ditangkupkan satu sama lain saling berhadapan dengan posisi cawan petri berisi $C$. acutatum berada di atas cawan petri $R$. minnuta. Kontrol dibuat dengan cara yang sama tanpa penambahan gula. Selain itu, dibuat perlakuan gula pada media PDA untuk melihat pengaruhnya terhadap pertumbuhan $C$. acutatum tanpa pemberian khamir $R$. minuta. Pengamatan pertumbuhan $C$. acutatum dilakukan setiap hari.

Pengamatan dilakukan dengan mengukur koloni $C$. acutatum. Persentase tingkat hambatan relatif dihitung dengan rumus seperti pada pengamatan kemampuan antagonisme $R$. minuta.

\section{HASIL DAN PEMBAHASAN}

\section{Pengujian Pengaruh Penambahan Gula terhadap Kerapatan sel $\boldsymbol{R}$. minuta}

Pertumbuhan khamir $R$. minuta pada larutan gula glukosa, sukrosa, trehalosa, D-mannitol dan Dxylosa dengan konsentrasi $1 \%, 2,5 \%$ dan 5\% berpengaruh terhadap kerapatan sel $R$. minuta. Khamir $R$. minuta dapat tumbuh pada gula yang diuji dan gula tersebut dapat meningkatkan kerapatan selnya (Tabel 1).

Tabel 1. Kerapatan sel $R$. minuta pada perlakuan penambahan gula dengan berbagai konsentrasi.

\begin{tabular}{|c|c|c|c|c|c|c|}
\hline \multirow{2}{*}{ Perlakuan } & \multicolumn{6}{|c|}{ Kerapatan sel $R$. minuta (sel $/ \mathrm{ml}$ ) pada pengamatan } \\
\hline & 24 jam & & 48 jam & & 72 jam & \\
\hline A. Glukosa $1 \%$ & $1,9 \times 10^{7}$ & a & $2,9 \times 10^{7}$ & $\mathrm{ab}$ & $3,7 \times 10^{7}$ & $\mathrm{~b}$ \\
\hline B. Glukosa $2,5 \%$ & $1,8 \times 10^{7}$ & a & $2,1 \times 10^{7}$ & $\mathrm{ab}$ & $1,8 \times 10^{7}$ & $\mathrm{ab}$ \\
\hline C. Glukosa 5\% & $2,1 \times 10^{7}$ & a & $2,5 \times 10^{7}$ & $\mathrm{ab}$ & $1,7 \times 10^{7}$ & $\mathrm{ab}$ \\
\hline D. Sukrosa $1 \%$ & $2 \times 10^{7}$ & a & $3,8 \times 10^{7}$ & $\mathrm{~b}$ & $3,4 \times 10^{7}$ & $\mathrm{~b}$ \\
\hline E. Sukrosa $2,5 \%$ & $1,5 \times 10^{7}$ & a & $2,5 \times 10^{7}$ & $\mathrm{ab}$ & $3,6 \times 10^{7}$ & $\mathrm{~b}$ \\
\hline F. Sukrosa 5\% & $2,1 \times 10^{7}$ & $\mathrm{a}$ & $2,4 \times 10^{7}$ & $\mathrm{ab}$ & $2,1 \times 10^{7}$ & $\mathrm{ab}$ \\
\hline G. Trehalosa 1\% & $1,1 \times 10^{7}$ & $\mathrm{a}$ & $1,9 \times 10^{7}$ & $\mathrm{a}$ & $2,0 \times 10^{7}$ & $\mathrm{ab}$ \\
\hline H. Trehalosa 2,5\% & $1,3 \times 10^{7}$ & $\mathrm{a}$ & $1,8 \times 10^{7}$ & $\mathrm{a}$ & $2,5 \times 10^{7}$ & $\mathrm{ab}$ \\
\hline I. Trehalosa 5\% & $1,6 \times 10^{7}$ & $\mathrm{a}$ & $2,2 \times 10^{7}$ & $\mathrm{ab}$ & $2,1 \times 10^{7}$ & $a b$ \\
\hline J. D-mannitol 1\% & $1.410^{7}$ & $\mathrm{a}$ & $1,2 \times 10^{7}$ & $\mathrm{a}$ & $2,6 \times 10^{7}$ & $\mathrm{ab}$ \\
\hline K. D-mannitol 2,5\% & $1,1 \times 10^{7}$ & $\mathrm{a}$ & $1,1 \times 10^{7}$ & $\mathrm{a}$ & $2,4 \times 10^{7}$ & $\mathrm{ab}$ \\
\hline L. D-mannitol 5\% & $1,510^{7}$ & $\mathrm{a}$ & $2,1 \times 10^{7}$ & $\mathrm{ab}$ & $2,5 \times 10^{7}$ & $\mathrm{ab}$ \\
\hline M. D-xylose 1\% & $2,4 \times 10^{7}$ & $\mathrm{a}$ & $2,4 \times 10^{7}$ & $\mathrm{ab}$ & $2,2 \times 10^{7}$ & $a b$ \\
\hline N. D-xylose $2,5 \%$ & $2 \times 10^{7}$ & $\mathrm{a}$ & $2,2 \times 10^{7}$ & $\mathrm{ab}$ & $2,6 \times 10^{7}$ & $\mathrm{ab}$ \\
\hline O. D-xylose 5\% & $1,6 \times 10^{7}$ & $\mathrm{a}$ & $2,4 \times 10^{7}$ & $\mathrm{ab}$ & $2,6 \times 10^{7}$ & $\mathrm{ab}$ \\
\hline P. Kontrol & $6 \times 10^{6}$ & $\mathrm{a}$ & $1,4 \times 10^{7}$ & $\mathrm{a}$ & $1,1 \times 10^{7}$ & $\mathrm{a}$ \\
\hline
\end{tabular}

Keterangan: Angka rata-rata yang diikuti oleh huruf yang berbeda menunjukkan perbedaan yang nyata berdasarkan uji Tukey pada taraf nyata $5 \%$

Kerapatan sel pada pengamatan 24 jam setelah perlakuan menunjukkan hasil yang tidak berbeda nyata dengan kontrol pada semua perlakuan. Akan tetapi, pada pengamatan 48 jam setelah perlakuan, kerapatan sel $R$. minuta mengalami peningkatan pada seluruh perlakuan kecuali perlakuan gula Dmanitol 2,5\%. Perlakuan penambahan sukrosa 1\% menunjukkan hasil yang berbeda nyata dengan kontrol dengan kerapatan sel $R$. minuta sebesar 3,8 x $10^{7} \mathrm{sel} / \mathrm{ml}$. Kerapatan sel $R$. minuta mengalami fluktuatif pada pengamatan 72 jam setelah perlakuan. Kerapatan sel $R$. minuta pada beberapa perlakuan di pengamatan 72 jam menunjukkan berbeda nyata dengan kontrol yaitu perlakuan penambahan glukosa $1 \%$, sukrosa $1 \%$ dan sukrosa 2,5\% (Tabel 1).

Berdasarkan pengamatan selama 72 jam, kerapatan sel tertinggi terjadi pada perlakuan sukrosa $1 \%$ dengan nilai kerapatan sel 3,8 x $10^{7}$ $\mathrm{sel} / \mathrm{ml}$ (Tabel 1). Haryadi (2013) melaporkan bahwa sukrosa dapat meningkatkan pertumbuhan khamir Saccharomyces cerevisiae. Sukrosa merupakan gula yang terbentuk dari glukosa dan fruktosa. Sumber gula sederhana seperti glukosa dan fruktosa sangat penting bagi khamir dalam masa awal pertumbuhan. Sukrosa akan dipecah menjadi glukosa dan fruktosa oleh khamir sehingga dapat meningkatkan kandungan gula dalam medium (Tana \& Isdadiyanto, 
2016). Akan tetapi, konsentrasi sukrosa yang tinggi dapat menurunkan pertumbuhan khamir. Hal ini disebabkan gula dalam konsentrasi tinggi dapat menyebabkan peningkatan tekanan osmotik di luar sel lebih tinggi daripada tekanan di dalam sel sehingga cairan yang ada di dalam sel tertarik keluar dan sel mengalami plasmolisis (Leepel dkk., 2009).

Kerapatan sel $R$. minuta pada pengamatan 24 jam setelah perlakuan menunjukkan hasil yang tidak berbeda nyata dengan kontrol pada seluruh perlakuan. Hal ini diduga disebabkan pada 24 jam setelah perlakuan khamir masih dalam fase adaptasi (fase lag). Pada pengamatan 48 jam setelah perlakuan, khamir $R$. minuta mengalami pertumbuhan yang cepat karena khamir $R$. minuta dapat memanfaatkan berbagai gula tersebut sebagai nutrisi. Hal ini menunjukkan bahwa khamir telah memasuki fase eksponensial (fase log). Akan tetapi, memasuki waktu 72 jam kerapatan sel $R$. minuta pada beberapa gula mengalami penurunan. Penurunan kerapatan sel ini terjadi diduga karena nutrisi yang tersedia mulai berkurang dan khamir memasuki fase stasioner.

Tabel 2. Hasil pengamatan pH pada media $R$. minuta dengan perlakuan beberapa gula.

\begin{tabular}{lcccc}
\hline \multirow{2}{*}{ Perlakuan } & \multicolumn{4}{c}{ Nilai pH pada pengamatan } \\
\cline { 2 - 5 } & 0 Jam & 24 Jam & 48 Jam & 72 jam \\
\hline A. Glukosa 1\% & 6,22 & 6,23 & 6,23 & 6,26 \\
B. Glukosa 2,5\% & 6,18 & 6,20 & 6,22 & 6,25 \\
C. Glukosa 5\% & 6,02 & 6,08 & 6,13 & 6,18 \\
D. Sukrosa 1\% & 6,15 & 6,21 & 6,22 & 6,25 \\
E. Sukrosa 2,5\% & 6,00 & 6,05 & 6,09 & 6,12 \\
F. Sukrosa 5\% & 6,19 & 6,21 & 6,21 & 6,22 \\
G. Trehalosa 1\% & 5,99 & 6,01 & 6,03 & 6,05 \\
H. Trehalosa 2,5\% & 6,02 & 6,03 & 6,05 & 6,07 \\
I. Trehalosa 5\% & 6,00 & 6,02 & 6,02 & 6,03 \\
J. D-Mannitol 1\% & 6,01 & 6,04 & 6,07 & 6,10 \\
K. D-Mannitol 2,5\% & 6,01 & 6,03 & 6,03 & 6,04 \\
L. D-Mannito 5\% & 6,03 & 6,05 & 6,06 & 6,09 \\
M. D-Xylose 1\% & 5,98 & 6,01 & 6,03 & 6,06 \\
N. D-Xylose 2,5\% & 6,00 & 6,05 & 6,06 & 6,8 \\
O. D-Xylose 5\% & 6,00 & 6,00 & 6,03 & 6,07 \\
P. Kontrol & 6,14 & 6,20 & 6,22 & 6,23 \\
\hline
\end{tabular}

Hasil pengamatan $\mathrm{pH}$ pada larutan dengan perlakuan beberapa gula menunjukkan bahwa penambahan gula tidak berpengaruh terhadap $\mathrm{pH}$. Nilai $\mathrm{pH}$ larutan dengan perlakuan beberapa gula berkisar antara 5,98 sampai 6,26 (Tabel 2). Nilai pH larutan gula yang diuji masih dalam batas optimal untuk pertumbuhan khamir,yaitu 1,5 sampai 8,5 sehingga tidak menghambat pertumbuhan $R$. minuta.

\section{Pengaruh Penambahan Gula terhadap Pertumbuhan Koloni $R$. minuta}

Perlakuan penambahan gula pada media PDA berpengaruh terhadap pertumbuhan koloni $R$. minuta. Perlakuan trehalosa 2,5\% menunjukkan perbedaan yang nyata dengan kontrol pada pengamatan 3 hari setelah perlakuan (hsp), dengan lebar koloni sebesar $5,7 \mathrm{~cm}$. Pertumbuhan koloni $R$. minuta mengalami peningkatan pada pengamatan 6 dan 9 hsp. Akan tetapi, pada pengamatan 6 dan 9 hsp seluruh perlakuan menunjukkan tidak berbeda nyata dengan kontrol berdasarkan analisis statistik. Lebar koloni terbesar terjadi pada pengamatan 9 hsp yaitu pada perlakuan trehalosa $5 \%$ sebesar $14,4 \mathrm{~cm}$ (Tabel 3).

Hasil penelitian ini menunjukkan bahwa trehalosa merupakan gula terbaik dalam meningkatkan pertumbuhan koloni sel $R$. minuta. Menurut Sedijani (2014) trehalosa merupakan gula non reduksi yang tidak mudah terdegradasi oleh faktor luar. Gula ini tidak mudah mengalami perubahan struktur fisika maupun kimia dalam berbagai kondisi lingkungan, misalnya terhadap perubahan suhu, $\mathrm{pH}$ dan status air. Trehalosa juga memiliki sifat sebagai biological stabilizing agent atau stress protecting agent (Shinohara et al., 2002). 
Penambahan trehalosa dalam konsentrasi yang tinggi tidak menyebabkan lisis pada sel, sebaliknya dapat meningkatkan pertumbuhan koloni $R$. minuta. Penggunaan media tumbuh yang berbeda dalam perlakuan penambahan gula dapat menyebabkan kerapatan sel dan pertumbuhan koloni $R$. minuta yang berbeda. Media yang berbeda akan berpengaruh terhadap nutrisi serta karakteristik gula yang ditambahkan.

Tabel 3. Pertumbuhan koloni $R$. minuta pada perlakuan penambahan gula.

\begin{tabular}{|c|c|c|c|c|c|c|}
\hline \multirow{3}{*}{$\begin{array}{l}\text { Perlakuan } \\
\text { A. Glukosa } 1 \%\end{array}$} & \multicolumn{6}{|c|}{ Lebar koloni $R$. minuta $(\mathrm{cm})$ pada } \\
\hline & \multicolumn{2}{|c|}{3 hsp } & \multicolumn{2}{|c|}{6 hsp } & \multicolumn{2}{|c|}{9 hsp } \\
\hline & 2,97 & $\mathrm{a}$ & 6,33 & $\mathrm{ab}$ & 8,53 & $\mathrm{ab}$ \\
\hline B. Glukosa 2,5 \% & 3,77 & $\mathrm{a}$ & 7,07 & $a b$ & 6,57 & $\mathrm{a}$ \\
\hline C. Glukosa 5\% & 2,77 & a & 4,43 & $\mathrm{a}$ & 6,83 & $\mathrm{a}$ \\
\hline D. Sukrosa 1\% & 3,93 & a & 8,27 & $\mathrm{~b}$ & 10,33 & abc \\
\hline E. Sukrosa $2,5 \%$ & 3,13 & a & 6,53 & $a b$ & 8,53 & $\mathrm{ab}$ \\
\hline F. Sukrosa 5\% & 3,43 & a & 6,20 & $a b$ & 9,07 & abc \\
\hline G. Trehalosa 1\% & 3,43 & a & 6,20 & $a b$ & 9,83 & abc \\
\hline H. Trehalosa 2,5\% & 5,70 & $\mathrm{~b}$ & 8,87 & $\mathrm{~b}$ & 13,10 & bc \\
\hline I. Trehalosa 5\% & 3,83 & a & 9,33 & $\mathrm{~b}$ & 14,40 & c \\
\hline J. D-Mannitol 1\% & 4,37 & $a b$ & 7,80 & $\mathrm{~b}$ & 11,80 & $a b c$ \\
\hline K. D-Mannitol 2,5\% & 3,80 & $\mathrm{a}$ & 7,10 & $a b$ & 11,13 & abc \\
\hline L. D-Mannito 5\% & 4,47 & $\mathrm{ab}$ & 8,10 & $\mathrm{~b}$ & 12,43 & bc \\
\hline M. D-Xylose 1\% & 4,20 & $a b$ & 8,50 & $\mathrm{~b}$ & 11,63 & $a b c$ \\
\hline N. D-Xylose 2,5\% & 3,33 & $\mathrm{a}$ & 7,17 & $a b$ & 9,77 & abc \\
\hline O. D-Xylose 5\% & 2,80 & $\mathrm{a}$ & 6,17 & $a b$ & 10,90 & abc \\
\hline P. Kontrol & 3,70 & $\mathrm{a}$ & 6,63 & $\mathrm{ab}$ & 9,00 & $\mathrm{abc}$ \\
\hline
\end{tabular}

Tabel 4. Kemampuan antagonisme khamir $R$. minuta terhadap $C$. acutatum dengan perlakuan penambahan gula pada 9 hsp.

\begin{tabular}{|c|c|c|c|c|}
\hline \multicolumn{2}{|r|}{ Perlakuan } & \multicolumn{2}{|c|}{ Jari-jari C. acutatum $(\mathrm{cm})$} & \multirow{2}{*}{$\frac{\text { Tingkat hambatanan relatif }(\%)}{8,62}$} \\
\hline A. & Glukosa 1\% & $4,13 \pm 0,18$ & abc & \\
\hline B. & Glukosa 2,5\% & $4,07 \pm 0,09$ & $a b c$ & 9,95 \\
\hline C. & Glukosa 5\% & $4,25 \pm 0,00$ & bc & 5,97 \\
\hline D. & Sukrosa 1\% & $4,00 \pm 0,00$ & $a b c$ & 11,50 \\
\hline E. & Sukrosa $2,5 \%$ & $3,87 \pm 0,18$ & $\mathrm{ab}$ & 14,38 \\
\hline F. & Sukrosa 5\% & $4,07 \pm 0,07$ & $a b c$ & 9,95 \\
\hline G. & Trehalosa $1 \%$ & $4,25 \pm 0,25$ & $\mathrm{abc}$ & 5,97 \\
\hline H. & Trehalosa 2,5\% & $4,32 \pm 0,23$ & bc & 6,41 \\
\hline I. & Trehalosa 5\% & $4,00 \pm 0,00$ & $a b c$ & 11,50 \\
\hline $\mathrm{J}$. & D-mannitol 1\% & $4,28 \pm 0,28$ & bc & 5,30 \\
\hline K. & D-mannitol 2,5\% & $4,20 \pm 0,20$ & $\mathrm{abc}$ & 7,07 \\
\hline L. & D-mannitol 5\% & $3,87 \pm 0,39$ & $\mathrm{ab}$ & 14,38 \\
\hline M. & D-xylosa 1\% & $3,67 \pm 0,44$ & $\mathrm{a}$ & 18,80 \\
\hline N. & D-xylosa 2,5\% & $4,05 \pm 0,06$ & $a b c$ & 10,39 \\
\hline O. & D-xylosa 5\% & $3,80 \pm 0,35$ & $\mathrm{ab}$ & 15,93 \\
\hline P. & Kontrol & $4,52 \pm 0,03$ & c & 0,00 \\
\hline
\end{tabular}


Pengaruh Penambahan Gula terhadap Kemampuan Antagonisme $R$. minuta

Hasil analisis statistik menunjukkan bahwa perlakuan penambahan gula pada media pengujian berpengaruh terhadap pertumbuhan jari-jari patogen C. acutatum. Beberapa perlakuan penambahan gula menunjukkan hasil yang berbeda nyata dengan kontrol. Perlakuan tersebut adalah sukrosa 2,5\%, trehalosa 5\%, D-mannitol 5\% dan Dxylosa $1 \%$. Nilai tingkat hambatan relatif pada perlakuan penambahan berbagai gula berkisar antara $5,30 \%$ sampai $18,80 \%$ dengan tingkat hambatan relatif tertinggi terjadi pada perlakuaan $\mathrm{D}$-xylosa $1 \%$ (Tabel 4).

Hasil pengamatan menunjukkan bahwa penambahan beberapa gula dengan konsentrasi yang berbeda menghasilkan peningkatan antagonisme khamir yang berbeda-beda (Tabel 4 dan Gambar 1). Menurut Addy (2008) setiap mikroba dapat memanfaatkan gula yang berbeda untuk meningkatkan antagonismenya. Gula D-xylose memiliki kecenderungan menghambat pertumbuhan jamur C. acutatum (Tabel 4 dan Gambar 1). Hal ini terlihat juga pada pengujian penambahan gula dalam media PDA tanpa khamir $R$. minuta (Gambar 2). Data pengujian penambahan gula dalam media PDA tanpa khamir $R$. minuta menunjukkan bahwa seluruh perlakuan penambahan gula mampu meningkatkan pertumbuhan $C$. acutatum, kecuali gula D-xylose. Akan tetapi, penambahan gula Dxylose tidak menghambat pertumbuhan $R$. minuta. Hal ini menunjukkan bahwa jamur $C$. acutatum tidak mampu memanfaatkan gula D-xylose, sedangkan $R$. minuta mampu memanfaatkan gula tersebut. Oleh karena itu, perlakuan dengan tingkat hambatan relatif tertinggi adalah sukrosa 2,5\% dan D-manitol 5\% (Tabel 4).

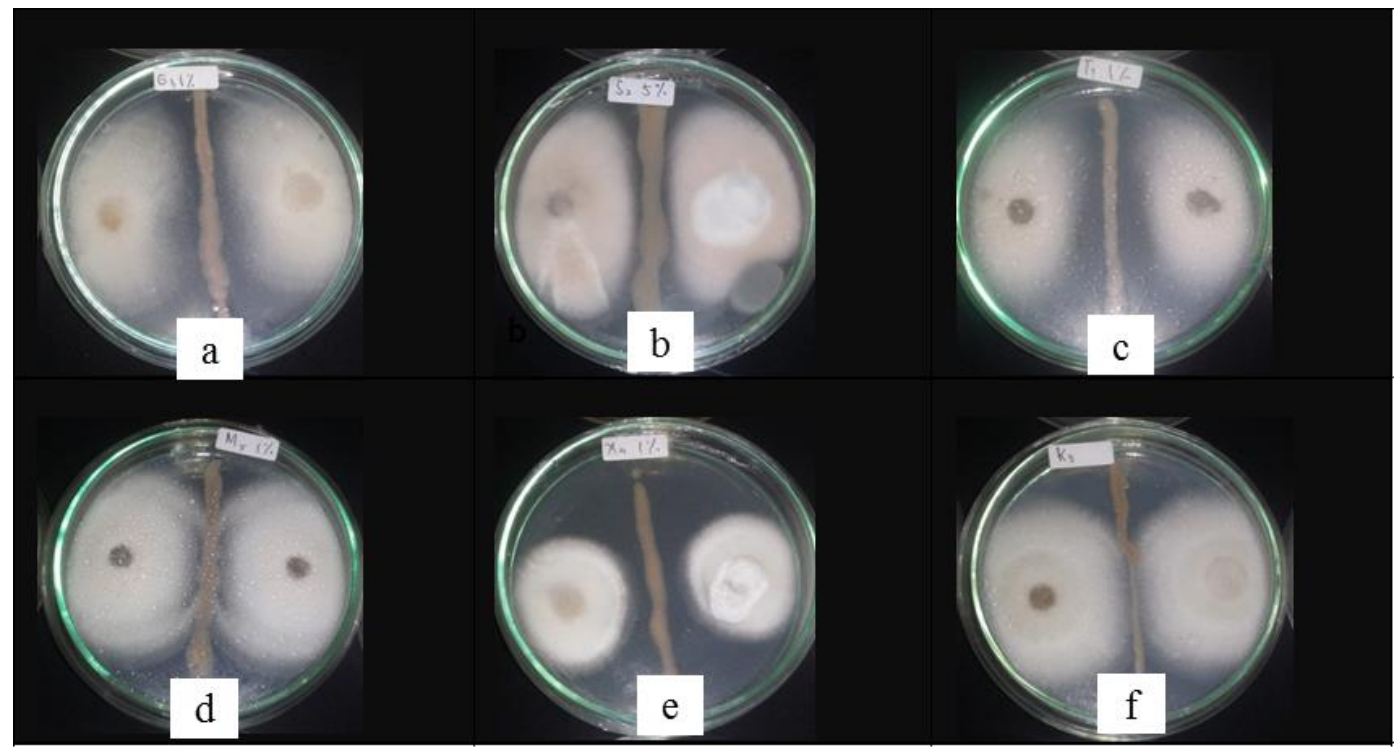

Gambar 1. Hasil uji antagonisme khamir $R$. minuta terhadap $C$. acutatum pada 9 hsp dengan perlakuan (a) glukosa 1\%, (b) sukrosa 1\%, (c) trehalosa 1\%, (d) D-mannitol 1\%, (e) D-xylose 1\%, dan (f) kontrol tanpa penambahan gula.

Uji antagonisme $R$. minuta dengan perlakuan penambahan gula menunjukkan bahwa perlakuan tersebut mampu meningkatkan kemampuan antagonisme $R$. minuta. Pertumbuhan hifa jamur $C$. acutatum terlihat semakin menipis pada daerah mendekati khamir $R$. minuta (Gambar 1). Kemampuan khamir $R$. minuta dalam menekan pertumbuhan $C$. acutatum diduga disebabkan khamir menghasilkan senyawa toksin dan enzim yang mampu menghambat pertumbuhan patogen. Hartati (2016) melaporkan bahwa $R$. minuta memiliki mekanisme antagonisme hiperparasit dan pembentukan senyawa volatil yang dapat menekan C. acutatum. Penambahan gula diduga mampu meningkatkan kemampuan $R$. minuta dalam menghasilkan senyawa toksin dan enzim. Khamir juga dikenal sebagai mikroba yang memiliki kemampuan dalam kompetisi nutrisi. 


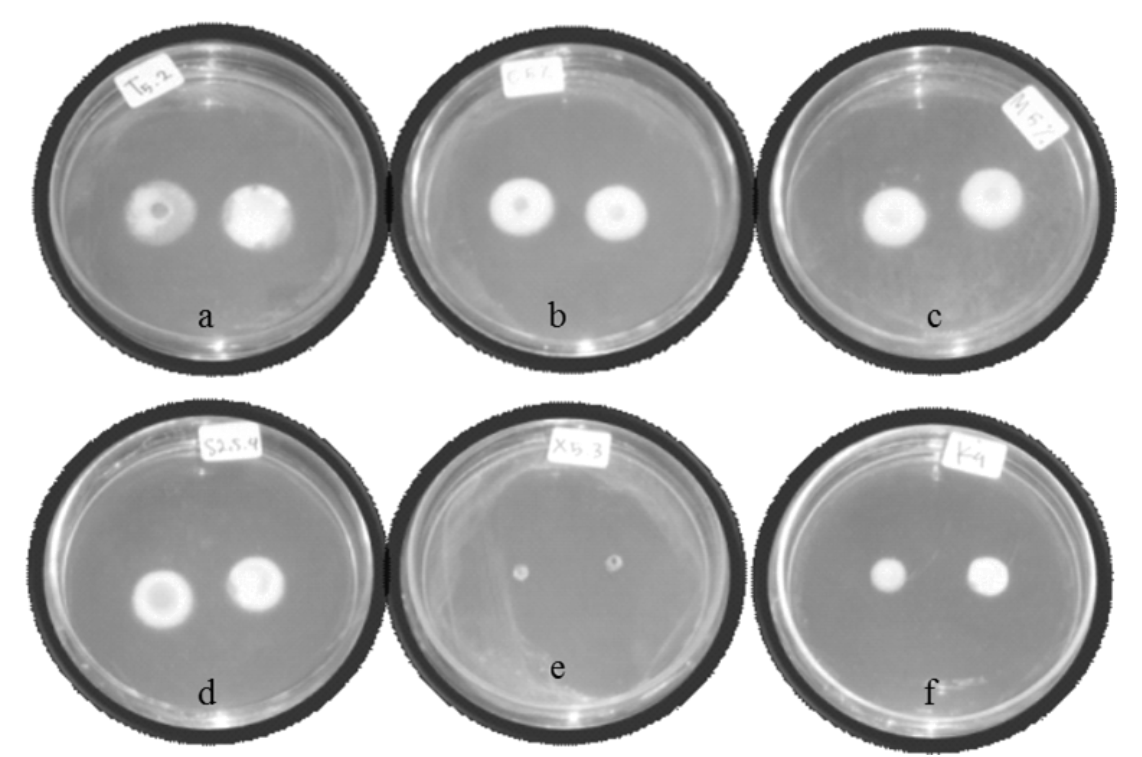

Gambar 2. Pertumbuhan C. acutatum tanpa $R$. minuta pada 4 hsp dengan perlakuan (a) trehalosa 5\%, (b) glukosa 5\%. (c) D-mannitol 5\%. (d) sukrosa 5\%. (e) D-xylose 5\%. (f) kontrol tanpa penambahan gula.

Tabel 6. Kemampuan antagonisme khamir $R$. minuta terhadap $C$. acutatum melalui pembentukan senyawa volatil dengan perlakuan penambahan gula pada 9 hsp.

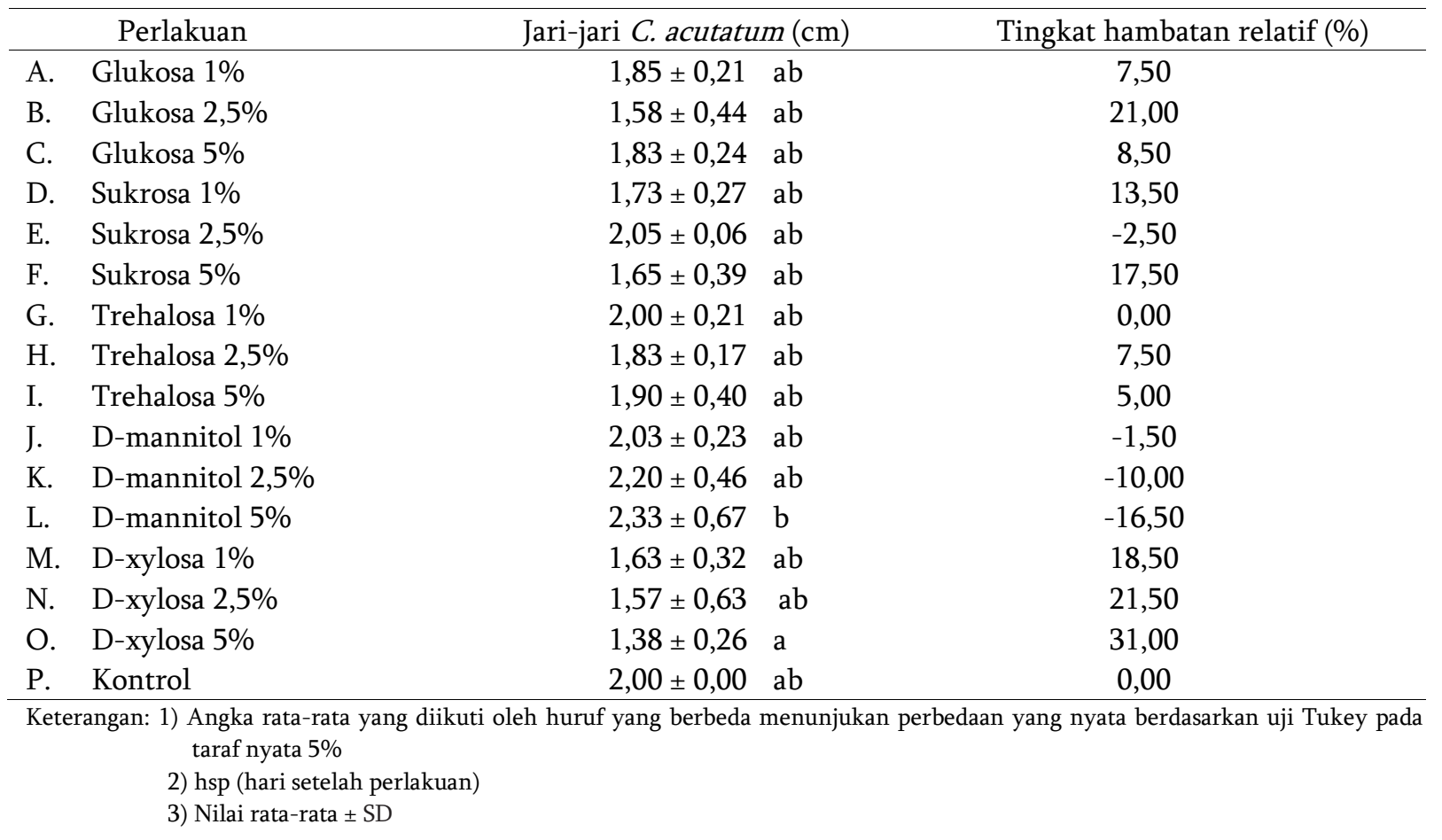

Pengaruh Penambahan Gula terhadap Peningkatan Antagonisme $R$. minuta melalui Pembentukan Senyawa Volatil

Hasil analisis statistik menunjukkan adanya pengaruh penambahan gula terhadap peningkatan antagonisme $R$. minuta melalui pembentukan senyawa volatil. Perlakuan penambahan gula Dxylosa 5\% menunjukkan nilai tingkat hambatan relatif tertinggi. Akan tetapi, hasil ini disebabkan D- xylosa menekan pertumbuhan $C$. acutatum dan $C$. acutatum tidak mampu memanfaatkan D-xylosa. Oleh karena itu, nilai tingkat hambatan relatif tertinggi yang disebabkan oleh adanya peningkatan antagonisme $R$. minuta melalui pembentukan senyawa volatil dengan perlakuan penambahan gula adalah perlakuan glukosa 2,5\% (Tabel 6 dan Gambar 3). 


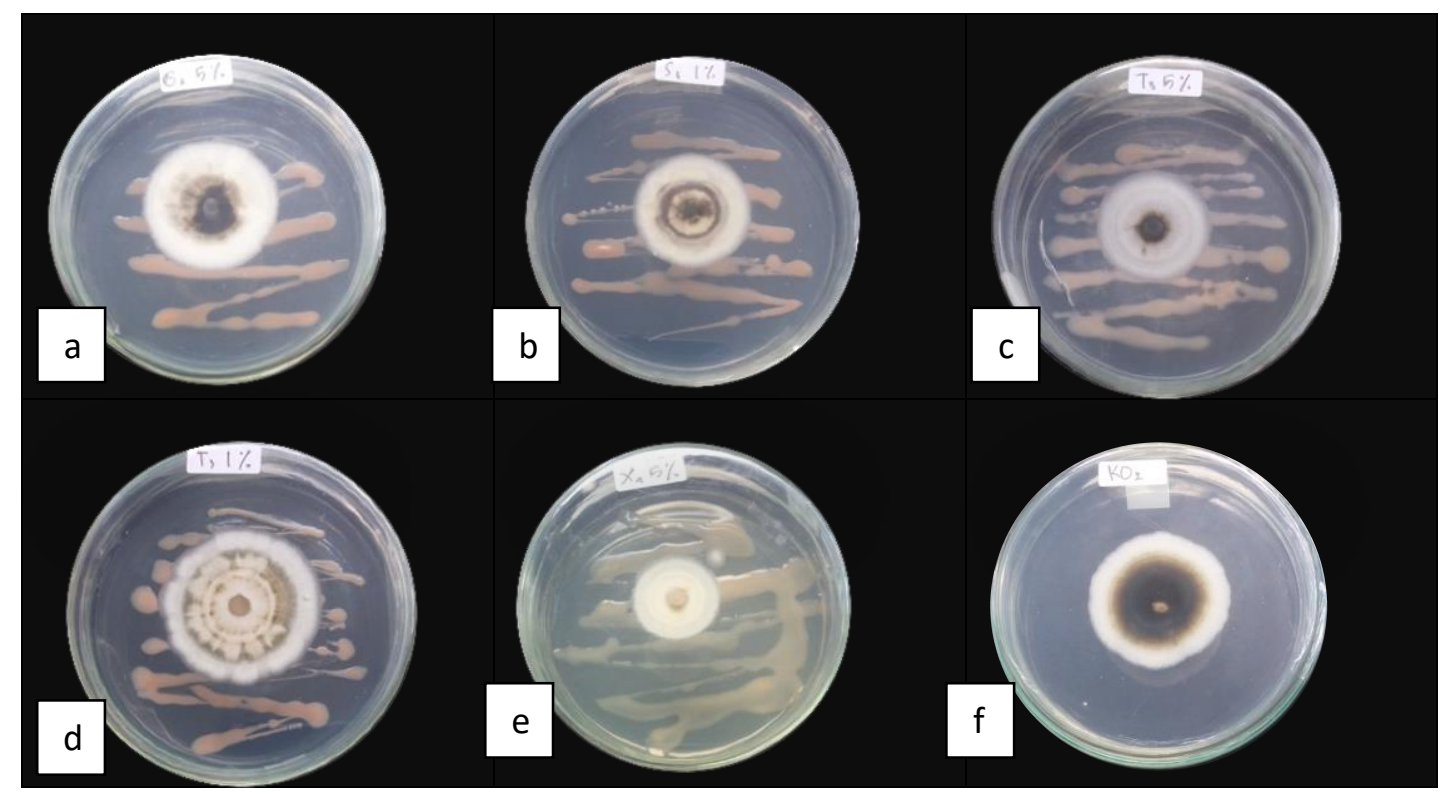

Gambar 3. Hasil uji antagonisme khamir $R$. minuta terhadap $C$. acutatum melalui pembentukan senyawa volatil pada 9 hsp dengan perlakuan (a) glukosa 5\%, (b) sukrosa 5\%, (c) trehalosa 5\%, (d) $D$ mannitol 5\%, (e) D-xylose 5\%, dan (f) kontrol tanpa penambahan gula.

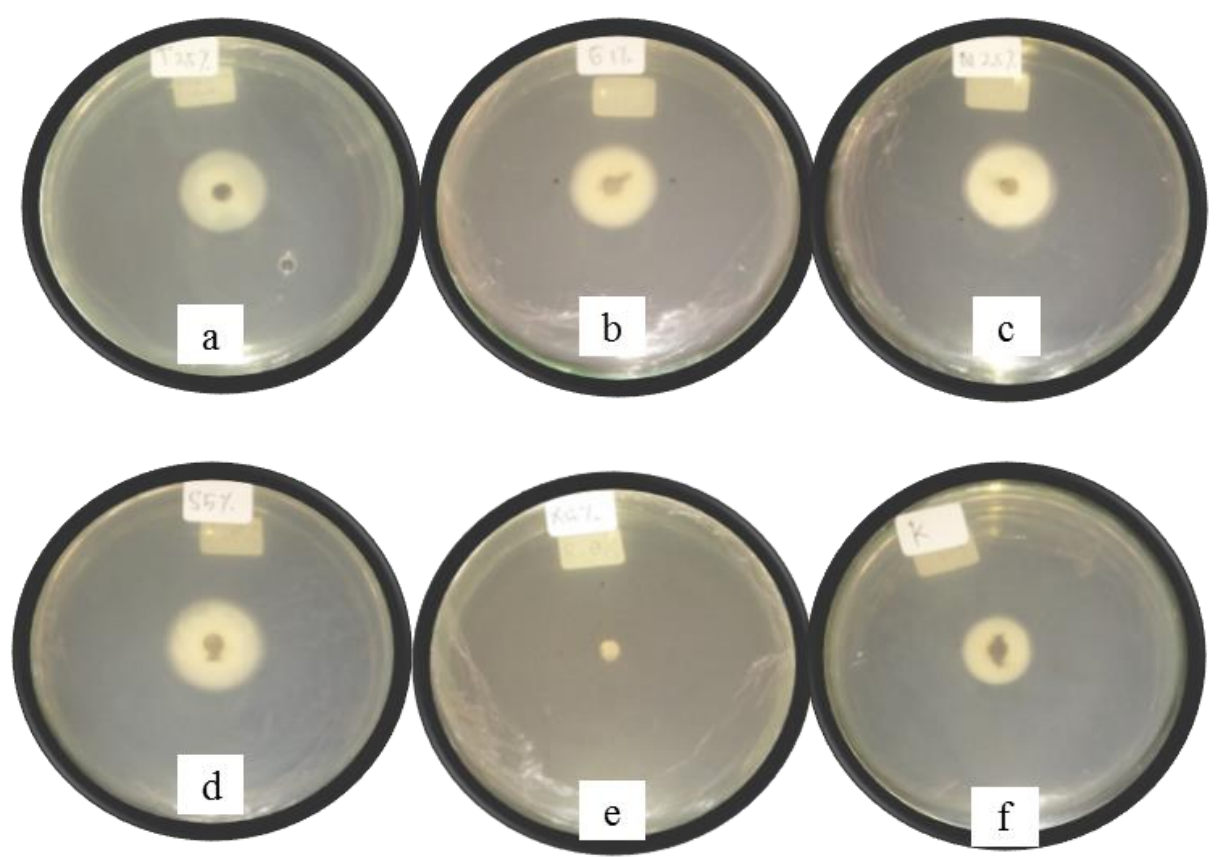

Gambar 4. Pertumbuhan $C$. acutatum tanpa $R$. minuta pada 4 hsp dengan perlakuan (a) trehalosa 5\%, (b) glukosa 5\%, (c) D-mannitol 5\%, (d) sukrosa 5\%, (e) D-xylose 5\%, dan (f) kontrol tanpa penambahan gula.

Penekanan D-xylosa terhadap pertumbuhan C. acutatum juga ditunjukkan pada hasil pengujian pengaruh penambahan gula terhadap $C$. acutatum dengan metode Huang (2011) tanpa $R$. minuta (Gambar 4). Perlakuan gula D-manitol menghasilkan nilai tingkat hambatan relatif negatif. Hal ini menunjukkan bahwa D-manitol tidak mampu meningkatkan kemampuan $R$. minuta dalam membentuk senyawa volatil.

Menurut Hermansyah et al. (2016) khamir mampu tumbuh pada media yang mengandung Dxylosa sebagai gula. Khamir akan mereduksi D- 
xylose menjadi xylitol melalui jalur katabolisme yang melibatkan enzim kunci yaitu xilose reduktase $(\mathrm{XR})$, xilitol dehidrogenase $(\mathrm{XDH})$ dan xilulokinase (XK). Xylitol merupakan gula alkohol yang memiliki struktur khusus sehingga sulit dicerna oleh mikroorganisme dan dapat menghambat pertumbuhan jamur (Aslim, 2014). Jamur C. acutatum tidak dapat memanfaatkan D-xylosa sehingga kekurangan nutrisi akibat persaingan nutrisi dengan $R$. minuta.

$$
\text { Menurut Suciyanti dkk. }
$$
pembentukan senyawa volatil dipengaruhi oleh waktu inkubasi, nutrisi, suhu dan kelembaban. Pembentukan senyawa volatil merupakan salah satu mekanisme antagonisme khamir $R$. minuta. Senyawa volatil adalah suatu senyawa yang mudah menguap menjadi gas. Jamur dapat menghasilkan senyawa volatil berupa campuran senyawa hidrokarbon sederhana seperti aldehid, keton, benzena, sikloheksena, alkohol, fenol thioalkohol, thioester dan turunannya. Senyawa volatil dapat dimanfaatkan sebagai mycofumigant dan dapat dijadikan infochemical yang dapat mencegah terjadinya infeksi patogen. Khamir $R$. minuta dapat menghasilkan senyawa volatil berupa 2-metil butanol, 3-metil butanol, dimetil trisulfida dan tiometil-1-propanol (Buzzini el at., 2005).

\section{SIMPULAN}

Penambahan gula glukosa, sukrosa, trehalosa, D-mannitol, dan D-xylosa mampu meningkatkan kerapatan sel dan pertumbuhan koloni $R$. minuta. Sukrosa $1 \%$ merupakan gula terbaik dalam meningkatkan kerapatan sel yaitu sebesar $3,8 \times 10^{7} \mathrm{sel} / \mathrm{ml}$ pada 48 jam setelah perlakuan, sedangkan trehalosa $2,5 \%$ merupakan gula terbaik dalam meningkatkan pertumbuhan koloni $R$. minuta dengan lebar koloni $14,4 \mathrm{~cm}$ pada pengamatan 9 hsp. Penambahan gula glukosa, sukrosa, trehalosa, dan D-mannitol juga mampu meningkatkan antagonisme $R$. minuta. Perlakuan dengan tingkat hambatan relatif tertinggi adalah sukrosa 2,5\%, D-manitol 5\%, dan glukosa 2,5\%.

\section{DAFTAR PUSTAKA}

Addy, HS. 2008. Pengaruh gula terhadap daya antagonistik bakteri pseudomonas pendar fluor terhadap Erwinia caratovora. Jurnal Pengendalian Hayati. 1: 12-16.

Ahmad, RZ. 2008. Pemanfaatan cendawan untuk meningkatkan produktivitas dan kesehatan ternak. Jurnal Litbang Pertanian. 27(3) : 1-9.
Aslim, F. 2014. Daya hambat xylitol terhadap pertumbuhan mikroorganisme rongga mulut (Streptococus mutans, Staphylococcus aurena dan Candida albicans) studi in-vitro [Skripsi]. Universitas Hasanuddin: Makasar. 79 hal. Repository Universitas Hasanuddin.

Badan Litbang Pertanian. 2016. Pengendalian penyakit antraknosa pada tanaman cabai. http://www.litbang.pertanian.go.id/berita/o ne/2630/. Diakses pada tanggal 14 Januari 2018.

Buzzini, P, A Martini, F Cappelli, UM Pagnoni, and P Davoli. 2013. A study on volatile organic compounds (VOCs) produced by tropicalis ascomycetous yeast. Antonie Van Leeuwenhoek. 84(4) : 301-311.

Druvefors UÄ. 2004. Yeast biocontrol of grain spoilage moulds-mode of action of Pichia anomala [dissertation]. Swedish University of Agricultural Sciences: Swedia (SE). 44pp. Available from: Acta Universitatis Agriculturae Sueciae, Agraria 466.

Hartati, S, S Wiyono, H Hendrastuti, dan MS Sinaga. 2016. Khamir sebagai agens biokontrol antraknosa (Colletotrichum acutatum) pada tanaman cabai pascapanen [disertasi]. Institut Pertanian Bogor: Bogor. 94 hal. Tersedia di: Repository Institut Pertanian Bogor.

Hartati, S, S Wiyono, SH Hidayat, dan MS Sinaga. 2017. Karakterisasi morfologi dan pemanfaatan sumber karbon oleh khamir antagonis patogen antraknosa. Jurnal Mikologi Indonesia 1(2): 47-60.

Hartati. S, S Wiyono, SH Hidayat, dan MS Sinaga. 2014. Seleksi khamir epifit sebagai agens antagonis penyakit antraknosa pada cabai. Jurnal Hortikultura 24(3) : 258-265.

Haryadi. 2013. Analisa kadar alkohol hasil fermentasi ketan metode kromatografi gas dan uji aktifitas Saccharomyces cereviceae secara mikroskopis [thesis]. Universitas Diponogoro: Semarang. 53 hal. Tersedia di: Repository Diponogoro University University.

Hermansyah, M Novia, dan Wiraningsih. (2016). Bioethanol production from cellulose by Candida tropicalis, as an alternative microbial agent to produce ethanol from lignocellulosic biomass. Sriwijaya Journal of Environment. 1(1): 10-13 
Huang R, GQ Li, J Zhang, L Yang, HJ Che, DH Jiang, and HC Huang. 2011. Disease control and pest management control of postharvest botrytis fruit rot of strawberry by volatile organic compounds of Candida intermedia. Phytopathology. 101:859-869.

Leepel, LA, R Hidayat, R Puspitawati, and BM Bahtiar. 2009. Efek penambahan glukosa pada saburoud dextrose broth terhadap pertumbuhan Candida albicans (Uji invitro). Indonesian Journal of Dentistry. 16(1) : 58-63.

Sedijani, P. 2014. Peran trehalosa metabolism sepanjang masa kehidupan tanaman. Jurnal Biologi Tropis. 14(2): 139-152.

Shinohara, ML, A Correa, D Bell-Pedersen, JC Dunlap, and JJ Loros. (2002). Neurospora clock-controlled gene 9 (ccg-9) encodes trehalose synthase: circadian regulation of stress responses and development. Eukaryot. (1):33-43.

Stankova B, J Vichova, and R Pokorny. 2011. Virulence of Colletotrichum acutatum isolates to several host plants. Acta univ agric et silvic Mendel Brun. LIX (3):161170.

Subagyo, S Margino, dan Triyanto. 2015. Pengaruh penambahan berbagai jenis gula, nitrogen dan fosfor pada medium deMan, rogosa and Sharpe (MRS) terhadap pertumbuhan asam laktat yang diisolasi sari intestinum udang penaedin. Jurnal Kelautan Tropis 18(3) : 127-132.

Suciyanti, S, E Sulistyowati, dan Y Fenita. 2015. Evaluasi nutrisi limbah kulit durian (Durio zibethinus) yang difermentasi jamur tiram putih (Pleurotus ostreanus) pada masa inkubasi yang berbeda. Jurnal Sain Peternakan Indonesia 10(2) : 77-86.

Susetyo, HP. 2017. Succes story dan stategic planning pengendalian OPT cabai merah di Indonesia secara ramah lingkungan. Direktorat Perlindungan Hortikultura.

Tana, S, dan S Isdadiyanto. 2016. Pengaruh waktu fermentasi teh kombucha kadar 50\% terhadap glukosa darah tikus putih. Prosiding Seminar Nasional from Basic Science to Comprehensive Education. Makassar 188-193. 